\title{
RETROSPECTIVE STUDY OF CLINICAL DISEASES AND DISORDERS OF CATTLE IN SIRAJGANJ DISTRICT IN BANGLADESH
}

\author{
M. A. S. Sarker*, M. Aktaruzzaman ${ }^{1}$, A. K. M. A. Rahman and M.S. Rahman \\ Department of Medicine, Bangladesh Agricultural University, Mymensingh-2202, Bangladesh \\ ${ }^{1}$ Assistant Manager, Milkvita, Srinagar, Munshiganj
}

\begin{abstract}
A retrospective-epidemiological study of cattle diseases/disorders was conducted at Baghabari Milking zone of Bangladesh starting from June 2008 to May 2012. Out of 22066 cases, $73.95 \%$ and $17.16 \%$ diseases/disorders were recorded in cows and calves respectively. About $58.42 \%, 23.56 \% 12.48 \%$ and $5.54 \%$ cases were general and systemic, infectious, production and reproductive and surgical diseases/disorders respectively. The most common general and systemic diseases/disorders were fever (17.91\%), anorexia (17.55\%) and weakness (14.71\%). Among infectious diseases, $78.2 \%, 7.02 \%$ and $6.32 \%$ respectively were mastitis, FMD and black quarter. The predominant production and reproductive diseases were milk fever $(33.48 \%)$, repeat breeder $(17.10 \%)$, retained placenta $(14.27 \%)$, metritis $(13.11)$ and anestrous $(11.44 \%)$. The most common surgical disorders were navel ill $(46.9 \%)$, wound $(20.19 \%)$, abscess $(8.99 \%)$ and urolithiasis $(8.67 \%)$. Statistically significant variation of diseases in different seasons was also noted. We recommend for undertaking research focusing on the causes of fever, anorexia and weakness as they were the most predominant general and systemic disorders of cattle. Control measure should be initiated to reduce the burden of mastitis, repeat breeder, retained placenta and anestrous which were most common production and reproductive diseases in the study area. A case control study may help to reveal the factors responsible for such a high level of occurrence of navel ill in calves. This study generated information which is valuable not only for the clinicians, researchers, animal health companies and policy planners but also for the academicians to update veterinary curricula.
\end{abstract}

\section{INTRODUCTION}

There are about 23.4 million cattle, 0.82 million buffaloes and 33.5 million goats in Bangladesh (DLS 1998). These animals are important for good quality meat, milk, leathers and a source of income to farmers. Livestock is an integrated part of our farming system and plays an important role in the traditional economy of Bangladesh. Among the various constraints to cattle, buffaloes and goats production, diseases are the most important which degraded the productivity of these animals (Sarker et al., 1999). Until the existence of diseases in a particular area is understood, it is difficult to plan systemic health program or formulate effective control strategies. Retrospective evaluation of clinical case records help to understand the predominant clinical problems and also their demographic and seasonal distribution in a particular area. Although some disease reports on the analysis of clinical case report of cattle from BAU veterinary clinic (Samad, 2001 and 2011, Rahman et al., 1972 ; Hossain et al.,1986; Das and Hasim, 1996), Haluaghat Upazila Veterinary Hospital, Mymensingh (Sarker et al., 1999) the report on clinical cases of cattle in Sirajgonj and nearby districts is rare (Pharo 1987). This paper describes the important clinical problems of cattle at Baghabari Milking zone of Bangladesh.

\section{MATERIALS AND METHODS}

The duration of the study was four years from June, 2008 to May, 2012 and the research area was at Shahzadpur, Ullapara under Sirajganj and Bera, Sathia, Faridpur under Pabna district of Bangladesh. A total of 22066 sick cattle were recorded. The class of cattle were recorded as calf (up to one year), heifer ( $>$ one year to calving), cow and bull. The clinical cases were recorded during the physical visit of the farms. The clinical diagnosis of the diseases were made based on the presenting clinical signs, clinical history, physical examination, laboratory diagnosis, gross postmortem lesion, and the responses to treatment (Kelly, 1979; Rosenberger, 1979; Samad 1996). Four years data were analyzed on the basis of age and sex of the cattle and seasons. The year was divided into three seasons namely summer (July to October), rainy (March to June), winter (November to February). The proportional prevalence of diseases and disorders were calculated in percentage of the total records. The variation of diseases according to class of cattle and season was analyzed by Chi-square test in $\mathrm{R}$ 3.0.1 statistical software.

\section{RESULTS AND DISCUSSION}

A total of 22066 cases were recorded during the period starting from June 2008 to May 2012. The distribution of the different types of cases according to the class of cattle is presented in Table 1 . Almost $74 \%$ of the total cases were recorded in cows and $17.16 \%$ in calves.

*Corresponding e-mail address: sayeedsarker@hotmail.com 


\section{A. S. Sarker and others}

\section{General and systemic diseases/disorders}

The frequency of general and systemic diseases/disorders is presented in Table 2 . The most common general and systemic diseases/disorders were fever (17.91\%), anorexia (17.55\%), weakness (14.51) and bloat (8.66\%).

Table 1. Overall distribution of diseases in different class of cattle

\begin{tabular}{|lcccccc|}
\hline Diseases/disorders & Calf $(\%)$ & Heifer (\%) & Cow (\%) & Bull (\%) & Total $\begin{array}{c}\text { Proportional } \\
\text { prevalence (\%) }\end{array}$ \\
\hline $\begin{array}{l}\text { General and } \\
\text { systemic }\end{array}$ & $2769(21.48)$ & $633(4.91)$ & $8638(67.01)$ & $850(6.59)$ & 12890 & 58.42 \\
Infectious & $265(5.09)$ & $221(4.25)$ & $4600(88.48)$ & $113(2.17)$ & 5199 & 23.56 \\
$\begin{array}{l}\text { Production and } \\
\text { Reproductive }\end{array}$ & - & $86(3.12)$ & $2668(96.88)$ & & 2754 & 12.48 \\
Surgical & $753(61.57)$ & $29(2.37)$ & $407(33.28)$ & $34(2.78)$ & 1223 & 100 \\
\hline $\begin{array}{l}\text { Total (\%) } \\
3787(17.16)\end{array}$ & $969(4.39)$ & $16313(73.93)$ & $997(4.52)$ & 22066 \\
\hline Significant in Chi-square test at $<<0.001$ & & & \\
\hline
\end{tabular}

\section{Fever}

The rectal temperature when recorded $\geq 103^{\circ} \mathrm{F}$ considered as fever (Radostits et al., 2007). We have recorded about $17.91 \%$ cases of fever of unknown aetiology but Rahman et al., (2012) reported a lower level of fever in cow $(5.1 \%)$. The differences in cattle density, breed, management system, ecology between study areas may be responsible for differences in etiology of fever. Further research is needed to explore the infectious and noninfectious causes of fever in cattle for treatment and control purposes.

\section{Anorexia/Inappetence}

Complete or partial loss of appetite was diagnosed in $17.55 \%$ of cases on the basis of history obtained from the owner. Relatively higher occurrences was reported by Samad (2001) who found 33.57\% cases of inappetence in cattle brought to Bangladesh Agricultural University Clinic, Mymensingh for the therapeutic purposes. Oral lesion, indigestion, fever, toxemia, stress, poisoning and a lot of others may be responsible for anorexia/inappetance which should be confirmed clinical examination and laboratory aid.

\section{Weakness}

About $14.71 \%$ cases were suffering from weakness. Malnutrition, parasitic diseases, debilitating diseases and other factors may be responsible for weakness but it should be studied properly using case control study.

\section{Bloat}

Bloat is clinically characterized by marked distension of abdomen with severe distress and dyspnea. About $9 \%$ cases were suffering from bloat in this study. It is mainly dietary origin and occurs most frequently in ruminants in Bangladesh (Sutradhar et al., 2000, Samad, 2001) who reported $1.73 \%$ and $1.83 \%$ bloat in cattle, respectively. Bloat if not treated early it is fatal. If some controllable risk factors of bloat can be identified, it might be possible to reduce the extent of this problem.

\section{Diarrhoea}

Diarrhoea is the increased frequency of defecation accompanied by feces containing an increased concentration of water and decreased in dry matter content. In this study $7.08 \%$ cattle was suffering from the nonspecific diarrhoea whereas $8.99 \%$ and $25.97 \%$ diarrhoea were described in cattle in Bangladesh by Hoque and Samad (1996)and Samad (2001), respectively. 
Retrospective study of clinical diseases and disorders of cattle

Diarrhea is an important cause of calf mortality. In this study the proportion of diarrhoea was higher in cows $(61.07 \%)$ than in calves (28.94\%) (Table 2). In all class of cattle the causes of diarrhoea should be known for proper treatment and control of this problem.

Table 2. Distribution of general and systemic diseases in cattle

\begin{tabular}{|c|c|c|c|c|c|c|}
\hline Diseases/conditions & Calf & Heifer & Cow & Bull & Total & $\begin{array}{l}\text { Proportional } \\
\text { prevalence }\end{array}$ \\
\hline Allergic dermatitis & 57 & 15 & 78 & 6 & 156 & 1.21 \\
\hline Anorexia & 201 & 83 & 1762 & 216 & 2262 & 17.55 \\
\hline Arthritis & 59 & 10 & 219 & 38 & 326 & 2.53 \\
\hline Bloat & 230 & 74 & 728 & 84 & 1116 & 8.66 \\
\hline Bottle jaw & 81 & 29 & 116 & 35 & 261 & 2.02 \\
\hline Colic & 17 & 5 & 94 & 5 & 121 & 0.94 \\
\hline Constipation & 11 & 16 & 145 & 21 & 193 & 1.49 \\
\hline Diarrhea & 264 & 57 & 557 & 34 & 912 & 7.08 \\
\hline Dysentery & 127 & & 352 & 13 & 492 & 3.82 \\
\hline Eye disease & 81 & 8 & 34 & 2 & 125 & 0.97 \\
\hline Fever & 460 & 176 & 1547 & 125 & 2308 & 17.91 \\
\hline Lameness & 119 & 45 & 543 & 90 & 797 & 6.18 \\
\hline Malnutrition & 376 & 30 & 475 & 41 & 922 & 7. 15 \\
\hline Otitis & - & - & 2 & - & 2 & 0.02 \\
\hline Partial paralysis & 7 & - & 17 & - & 24 & 0.19 \\
\hline Pneumonia & 94 & 20 & 202 & 19 & 335 & 2.59 \\
\hline Udder edema & - & - & 602 & - & 602 & 4.67 \\
\hline Posthitis & - & - & - & 39 & 39 & 0.30 \\
\hline Weakness & 585 & 65 & 1165 & 82 & 1897 & 14.71 \\
\hline Total (\%) & $2769(21.48)$ & $633(4.91)$ & $8638(67.01)$ & $850(6.59)$ & 12890 & \\
\hline
\end{tabular}


M. A. S. Sarker and others

Table 3. Distribution of infectious diseases in cattle

\begin{tabular}{|c|c|c|c|c|c|c|}
\hline Disease & Calf & Heifer & Cow & Bull & Total & $\begin{array}{c}\text { Proportional } \\
\text { prevalence }\end{array}$ \\
\hline Actinomycosis & - & - & 6 & - & 6 & 0.11 \\
\hline Anthrax & 4 & 11 & 32 & 4 & 51 & 0.98 \\
\hline Black Quarter & 186 & 90 & 29 & 24 & 329 & 6.32 \\
\hline $\begin{array}{l}\text { Haemorrhagic } \\
\text { Septicemia }\end{array}$ & 5 & - & 6 & - & 11 & 0.21 \\
\hline Mastitis & - & - & 4056 & - & 4056 & 78.02 \\
\hline Tetanus & 21 & 4 & - & - & 25 & 0.48 \\
\hline Babesiosis & - & - & 105 & - & 105 & 2.02 \\
\hline Coccidiosis & 4 & - & - & - & 4 & 0.08 \\
\hline Ephemeral Fever & 45 & 73 & 73 & 56 & 247 & 4.75 \\
\hline FMD & & 43 & 293 & 29 & 365 & 7.02 \\
\hline Total (\%) & $265(5.09)$ & $221(4.25)$ & $4600(88.48)$ & $113(2.17)$ & 5199 & \\
\hline
\end{tabular}

\section{Infectious diseases}

The infectious diseases of cattle recorded in this study is presented in Table 3 . The most common infectious causes of cattle disease was mastitis (78.02\%). The other predominant infectious diseases were FMD (7.02\%), black quarter $(6.32 \%)$ and ephemeral fever $(4.75 \%)$.

\section{Mastitis}

Mastitis, an economically important disease of milch animal, was diagnosed on the basis of history and physical abnormalities of udder (Radostits, et al. 2007). Mastitis was observed in $78.02 \%$ of the infectious diseases recorded during the study period. Rahman et al. (1997) reported $13.3 \%$ of clinical mastitis in cows. However, comparatively lower proportion of mastitis was reported by Samad, (2001). This study reveals that mastitis is the most important infectious disease in cow of the study area. The incidence of mastitis has been reduced significantly world-wide by applying some control measures like treatment of clinical cases, selective dry cow therapy, pre and post milking teat disinfection and improved sanitation of the environment (Tyler et al., 1997; Bradely, 2002; Berry and Hillerton, 2002). Offering feed to cows after milking to make them in standing condition for some time and administration of vitamin and selenium 5-10 days before calving had also been found to reduce incidence of mastitis in dairy cattle (Smith et al., 1997; Tyler et al., 1997). It is possible to apply all of them in Bangladesh context except dry cow therapy. Because the long acting antibiotics used for dry cow therapy is not available in market. Importing antibiotics is very time consuming and government policy does not allow import antibiotics from developing country like India where it is widely used and readily available. To implement other control strategies, farmers motivation through extension work is needed. Active milk inspection service and setting milk price based not only on milk fat percentage but also on herd milk somatic cell count (the lower the cell count the higher the price) will also indirectly influence farmers to control mastitis in their herds. 
Retrospective study of clinical diseases and disorders of cattle

Table 4. Distribution of reproductive and production diseases in cattle

\begin{tabular}{|lcccc|}
\hline Diseases/disorders & Heifer (\%) & Cow (\%) & Total & Proportional Prevalence \\
\hline Abortion & - & 4 & 4 & 0.14 \\
Agalactiae & - & 18 & 18 & 0.65 \\
Anoestrus & 86 & 229 & 315 & 11.44 \\
Cystic Ovary & - & 18 & 18 & 0.65 \\
Dystocia & - & 77 & 77 & 2.79 \\
Infertility & - & 8 & 8 & 0.29 \\
Metritis & - & 361 & 361 & 13.11 \\
Milk fever & - & 922 & 922 & 33.48 \\
Repeat breeding & - & 471 & 471 & 17.10 \\
Retained placenta & - & 393 & 393 & 14.27 \\
Uterine prolapse & - & 143 & 143 & 5.19 \\
Vaginal prolapse & -26 & 24 & 0.87 \\
\hline \multicolumn{1}{|c}{ Total (\%) } & $(3.12)$ & $2668(96.88)$ & 2754 & $100 \%$ \\
\hline
\end{tabular}

Foot and Mouth Disease (FMD)

About $7.02 \%$ of the infectious diseases were FMD. The occurrence of FMD has been reported in all age groups of animals and all the seasons of the years but higher susceptibility to young's and associated with increased movement of animals at the start of dry winter grazing season in Pabna district (Pharo, 1987). FMD is a transboundary animal disease (Rweyemamu et al., 2008). Even after appropriate vaccination it is very difficult to control unless and until cattle trafficking is stopped and quarantine is followed appropriately during import from international market.

\section{Black quarter}

Black quarter was recorded in $6.32 \%$ of infectious diseases. In cattle the disease is mostly confined to young stock between 6 months to 2 years but occasionally it may occur in younger animals and cattle up to 3 years (Radostits et al., 2007). It is evident in our study that some cows and bulls were also affected with black quarter.

\section{Production and reproductive disorders}

The distribution of production and reproductive diseases is presented in Table 4 . About $33.48 \%$ of the production and reproductive disease was milk fever. Repeat breeder (17.10\%), retained placenta (14.27\%) and anestrous (11.44\%) were most common reproductive diseases. Khair et al. (2013) also observed higher occurrence of these diseases in the same area. Our clinical experience and opinion from field veterinarian are also in agreement with the findings of this study. 


\section{A. S. Sarker and others}

As unskilled veterinary practitioners at village level are not able to treat these complex diseases, their prevalence are increasing day by day. The detail epidemiology of these diseases should be known to undertake appropriate control measures.

Table 5. Distribution surgical diseases in cattle

\begin{tabular}{|c|c|c|c|c|c|c|}
\hline & Calf & Heifer & Cow & Bull & Total & $\begin{array}{c}\text { Proportional } \\
\text { Prevalence }(\%)\end{array}$ \\
\hline Abscess & 14 & 13 & 75 & 8 & 110 & 8.99 \\
\hline $\begin{array}{l}\text { Abscess of } \\
\text { anus }\end{array}$ & 3 & - & - & - & 3 & 0.25 \\
\hline Brocken horn & - & - & 19 & - & 19 & 1.55 \\
\hline Dermoid Cyst & 6 & - & - & - & 6 & 0.49 \\
\hline Fracture & 10 & - & 24 & - & 34 & 2.78 \\
\hline Haematoma & - & - & 4 & - & 4 & 0.33 \\
\hline Hernia & 4 & - & - & - & 4 & 0.33 \\
\hline Hip dislocation & - & - & 5 & - & 5 & 0.41 \\
\hline Navel ill & 574 & - & - & - & 574 & 46.93 \\
\hline Rectal Prolapse & 4 & - & - & - & 4 & 0.33 \\
\hline Teat fistula & - & - & 10 & - & 10 & 0.82 \\
\hline Teat polyps & - & - & 64 & - & 64 & 5.23 \\
\hline Udder Wound & - & - & 33 & - & 33 & 2.69 \\
\hline Urolithiasis & 98 & - & - & 8 & 106 & 8.67 \\
\hline Wound & 40 & 16 & 173 & 18 & 247 & 20.19 \\
\hline Total (\%) & 753 (61.57) & $29(2.37)$ & 407 (33.28) & $34(2.78)$ & 1223 & \\
\hline
\end{tabular}

\section{Surgical diseases}

Out of a total of 1223 surgical cases $46.93 \%$ were navel ill or omphalitis in calves. It may be prevented by improving maternity pen hygiene, reducing calf residency time inunhygienic calving pens, ensuring adequate early intake ofgood quality colostrum and repeated cord dipping with chlorhexidine (Waltner-Toews et al., 1986; Gorden and Plummer, 2010). Further study is needed to know whether it has any link with genetics or not as semen of Jersey bulls are also used in this area for breeding purpose. Whereas in all the other parts of Bangladesh, semen from Holstein Friesian bulls are predominantly used for artificial insemination.

Through this retrospective epidemiologic study, important diseases and disorder have been identified and hopefully on a priority basis control measures should be undertaken against them This study generated information which is valuable not only for the clinicians, researchers, animal health companies and policy planners but also for the academicians to update veterinary curricula. 
Table 6. Seasonal distribution of cattle diseases

\begin{tabular}{|lccccc|}
\hline & Summer (\%) & Winter (\%) & Rainy (\%) & Total & $\begin{array}{c}\text { Proportional } \\
\text { prevalence }\end{array}$ \\
\hline Cow & $6663(40.84)$ & $3906(23.94)$ & $5744(35.21)$ & 16313 & 73.93 \\
Bull & $331(33.19)$ & $389(39.02)$ & $277(27.78)$ & 997 & 4.52 \\
Calf & $356(36.74)$ & $202(20.85)$ & $411(42.41)$ & 969 & 4.39 \\
\hline Total (\%) & $1575(41.59)$ & $1061(28.02)$ & $1151(30.39)$ & 3787 & 17.16 \\
\hline Significant in Chi-square test at $\mathrm{p}<0.001$ & & $7583(34.37)$ & 22066 & $100 \%$ \\
\hline
\end{tabular}

\section{REFERENCES}

1. BradleyAJ (2002). Bovine mastitis: an evolving disease. The Veterinary Journal 164(2): 116-128.

2. Berry EA and Hillerton JE (2002). The effect of selective dry cow treatment on new intramammary infections. Journal of Dairy Science85(1): 112-121.

3. Das BC and Hashim MA (1996). Studies on surgical affections in calves. Bangladesh Veterinary Journal. 30: $53-57$

4. Directorate of Livestock Services (1998). Charjochrome O Chromobicus. Published By DLS,Dhaka-1215.P. 81 .

5. Gorden PJ and Plummer P (2010). Control, management, and prevention of bovinerespiratory disease in dairy calves and cows. Veterinary Clinics of North America: Food Animal Practice 26:243-259.

6. Hashim MA and Das BR (1997). Clinicall aspects of some surgical affections in calves. Bangladesh Journal of Animal Science. 26:13-19.

7. Hoque MS and Samad MA (1996). Prevalence of clinical diseases in dairy cross-bred cows and calves in the urban areas in Dhaka. Bangladesh Veterinary Journal. 30:118-129.

8. Hossain MA, Shaidullah M and Ali MA (1986). A report on surgical diseases and reproductive disorders recorded at the veterinary hospital of Bangladesh Agriculture University, Mymensingh. Bangladesh Veterinary Journal. 20:1-5.

9. Kelly,WR (1979). Veterinary Clinical Diagnosis, Second Ed.1974. Bailliere, Tandall and Cassel Ltd. London 39-102.

10. Khair A, AlamMM, RahmanAKMA, IslamMT, Azim A and ChowdhuryEH (2013). Incidence of reproductive and production diseases of cross-bred dairy cattle in Bangladesh. Bangladesh Journal of Veterinary Medicine 11(1): 31-36.

11. Pharo HJ (1987). Analysis of clinical case records from dairy co-operatives in Bangladesh. Tropical Animal Health Production. 19:136-142.

12. Radostits OM, Gay CC, Hinchcliff KW and Constable PD (2007). A textbook of the diseases of cattle, horses, sheep, pigs and goats. Veterinary Medicine. 10th ed. London: Saunders.

13. Rahman MA, Ali KM and Rahman A (1972). Incidence of diseases of cattle in Mymensignh. Bangladesh Veterinary Journal 6:25-30.

14. Rahman MM, Ali M and Hashem A (1997). Livestock disease problems in a selected area of Sherpur district. Bangladesh Journal of Training and Development 12: 205-210.

15. Rahman MS, Nooruddin M and Rahman MM (1997). Prevalence and distribution of mastitis in cross-bred and exotic dairy cows. Bangladesh Veterinarian. 14:1-4. 


\section{A. S. Sarker and others}

16. Rweyemamu M, Roeder P, Mackay D, Sumption K, Brownlie J, Leforban Y, Valarcher JF, Knowles NJ and Saraiva V (2008). Epidemiological Patterns of Foot-and-Mouth Disease Worldwide. Transboundary and Emerging Diseases 55 (1): 57-72.

17. Rosenberger G (1979). Clinical examination of Cattle $2^{\text {nd }}$ edn., Varlag Paul Parey, Berlin, Germany.

18. Samad M A (2011). Public health threat caused by zoonotic diseases in Bangladesh. Bangladesh Journal of Veterinary Medicine 9 (2):95-120.

19. Samad MA (1996). Poshu Palon O Chikisabidhya. Ist Pub. LE Prokasoni, BAU Camus, Mymensingh.

20. Samad MA (2001). Observation of clinical diseases in ruminants at the Bangladesh Agriculture University veterinary clinic. Bangladesh Veterinary Journal 35:93-120.

21. Sarker MAS, Hashim MA, Rahman MB and Begum H (1999). Studies on prevalence of diseases of animals (medicinal and surgical) in a Thana of Bangladesh. Progressive Agriculture 10:165-167.

22. Smith KL, Hogan JS and Weiss WP (1997). Dietary vitamin E and selenium affect mastitis and milk quality. Journal of Animal Science 75(6): 1659-1665.

23. Tyler JW, Fox LK,Parish SM, Swain J, Johnson DL, Grasseschi HA and Gant R (1997). Effect of feed availability on post-milking standing time in dairy cows. Journal of Dairy Research64(04): 617-620.

24. Waltner-Toews D, Martin SW and Meek AH (1986). Dairy calf management, morbidityand mortality in Ontario Holstein herds. IV. Association of managementwith mortality. Preventive Veterinary Medicine 4:159-171. 